\title{
Physiological effects of nickel chloride on the freshwater cyanobacterium Synechococcus sp. IU 625
}

\author{
Brian Nohomovich $^{1}$, Bao T. Nguyen ${ }^{2}$, Michael Quintanilla ${ }^{1}$, Lee H. Lee ${ }^{3}$, Sean R. Murray ${ }^{2}$, \\ Tin-Chun Chu ${ }^{1}$
}

\author{
${ }^{1}$ Department of Biological Sciences, Seton Hall University, South Orange, USA \\ ${ }^{2}$ Department of Biology, California State University Northridge, Northridge, USA \\ ${ }^{3}$ Department of Biology \& Molecular Biology, Montclair State University, Montclair, USA \\ Email: Tin-Chun.Chu@shu.edu
}

Received 30 May 2013; revised 21 June 2013; accepted 1 July 2013

Copyright (C) 2013 Brian Nohomovich et al. This is an open access article distributed under the Creative Commons Attribution License, which permits unrestricted use, distribution, and reproduction in any medium, provided the original work is properly cited.

\begin{abstract}
Harmful algal blooms (HABs) are a serious environmental problem globally. The ability of cyanobacteria, one of the major causative agents of HABs, to grow in heavy metal polluted areas is proving a challenge to environmental restoration initiatives. Some cyanobacteria secrete toxins, such as microcystin, that are potentially dangerous to animals and humans. In this study, the physiology of a cyanobacterium was assessed to nickel chloride exposure. Cell growths were monitored throughout the study with various nickel chloride concentrations ( $0,10,25$ or $50 \mathrm{mg} / \mathrm{L})$. Morphological abnormalities were observed with microscopic image analyses. Inductively coupled plasma mass spectrometry (ICP-MS) was carried out to trace the distribution of nickel during the growth period. This study provides insight on potential nickel response mechanisms in freshwater cyanobacteria, which may lead to effective HAB prevention strategy development.
\end{abstract}

Keywords: Harmful Algal Blooms (HABs); Cyanobacteria; Nickel Chloride; Stress Response; ICP-MS

\section{INTRODUCTION}

The formation of algal blooms is a serious concern around the world. Algal blooms can result from the use of pesticides, fertilizer, and waste [1]. The nutrient-enriched environments cause a dramatic increase in the cyanobacteria population. Many species of cyanobacteria secrete toxic metabolites [1,2]. These toxins have been linked to various diseases and are considered a factor in
Alzheimer's disease [2]. Monitoring of global water environments has become a human health imperative. The way cyanobacteria survive in heavy metal environments needs to be further evaluated.

The freshwater cyanobacterium, Synechococcus sp. IU 625 (S. IU 625) is a unicellular rod-shaped microorganism with a similar cell wall structure to gram-negative bacteria [3]. S. IU 625 is an ideal candidate to study heavy metal response mechanisms due to its fast growth, easy maintenance and cultural conditions [3]. The unique nature of cyanobacteria to grow in a wide range of environments conditions makes them ideal model organisms. Using S. IU 625 as a model, many biological processes can be assessed including cell biology, membrane transport and various molecular mechanisms.

Previous studies have shown that increasing concentrations of heavy metals can slow cell growth [3-13]. Nickel is an essential metal that plays an important role in cellular physiology for eukaryotes and prokaryotes. Nickel is a necessary cofactor for enzymatic function in prokaryotes [14]. High concentrations of nickel exposure could be potentially harmful. Nickel has been shown to cause detrimental damage to lung tissue $[15,16]$ and is categorized as a potential carcinogen. It is also on the Environmental Protection Agency Target Analyte List [17]. In human cell lines nickel accumulates intracellularly and effects DNA methylation and iron-uptake systems resulting in iron deficiency [16].

Previous work has shown that $S$. IU 625 sequesters or utilizes an efflux mechanism to maintain homeostasis of heavy metals $[3,18]$. This study provides insight into the effects nickel chloride has on S. IU 625 and the response it utilizes to reduce nickel toxicity. Transcription of $s m t A$, which encodes metallothionein, has been shown to increase heavy metal resistance. 


\section{MATERIALS AND METHODS}

\subsection{Culture Maintenance}

S. IU 625 stock cultures were maintained in an incubator shaker (Amerex Instruments Inc.) at $26^{\circ} \mathrm{C}$ with continuous agitation at $100 \mathrm{rpm}$ and constant fluorescent light. Five $\mathrm{ml}$ of cells were inoculated in $95 \mathrm{ml}$ of sterilized Mauro's Modified Medium (3M) [19] in $250 \mathrm{ml}$ Erlenmeyer flasks. The $\mathrm{pH}$ of the $3 \mathrm{M}$ medium was adjusted to 7.9.

\subsection{Preparation of Nickel Chloride Solution}

A nickel chloride (1\%) stock solution was prepared using triple distilled water (Milli-Q Integral 5 Water Purification System, EMD Millipore, MA) in a sterile container from Sigma Aldrich. Solution was filtered with $0.45 \mu \mathrm{m}$ Millipore membrane filters.

\subsection{Growth of Synechococcus sp. IU 625 in the Presence of Nickel Chloride}

Nickel chloride was added at varying concentrations ( 0 , $10,25,50 \mathrm{mg} / \mathrm{L}$ ) to exponentially growing cultures in four separate $250 \mathrm{ml}$ Erlenmeyer flasks. Cell growth was observed by: 1) Direct counts with hemacytometer; 2) Turbidity study, optical density (OD) was taken by using a spectrophotometer at $750 \mathrm{~nm}$ wavelength. Three repeatings of this experiment were carried out and the growth was monitored for 28 days. Mean and standard deviations were generated through GraphPad Prism.

\subsection{Heavy Metal Distribution}

Immediately after collection, samples were centrifuged and the supernatant placed into a different microcentrifuge tube and labeled. Adding $\mathrm{dH}_{2} \mathrm{O}$ to the cell pellet up to $1 \mathrm{~mL}$ resuspended the cells. Nickel concentrations in the cells and supernatant were determined by using an ELAN DRC-E ICP-MS following an ICP-MS protocol [20] at Naturex, Inc.

\subsection{Microscopic Observations}

One $\mathrm{ml}$ of culture was taken at each time point and used for analysis. Cells were immediately centrifuged for 1 minute and the supernatant discarded and then fixed with $12.5 \%$ formaldehyde in phosphate buffer. DAPI $(4,6-$ diamidion-2-phenylindole) fluorescence was used to detect DNA. Two microgram per milliliter of DAPI was added to cells and incubated for 10 minutes in the dark and then added onto a $1 \%$ agarose pad. A Zeiss AxioVision microscope (with a Hamamatsu ORCA-ER digital camera) was used to observe cell morphology using differential contrast.

\section{RESULTS}

\subsection{S. IU 625 Tolerates Up to $25 \mathrm{mg} / \mathrm{L}$ of Nickel Chloride}

To determine the effects of nickel chloride on the growth of $S$. IU 625, cultures were grown in $3 \mathrm{M}$ medium with increasing concentrations of nickel chloride $(0,10,25$ or $50 \mathrm{mg} / \mathrm{L}$ ). Cells were monitored for 28 days to see the complete bacterial growth cycle. Collections were taken twice a week during each study. Growth curves indicate that cultures with increasing nickel chloride concentrations resulted in depressed growth until a certain nickel threshold concentration is reached (Figure 1).

The $10 \mathrm{mg} / \mathrm{L}$ culture initially exhibited slower growth compared to the control but recovered after a few days. However, growth of the cells under $10 \mathrm{mg} / \mathrm{L} \mathrm{NiCl}_{2}$ remained lower than the control. The $25 \mathrm{mg} / \mathrm{L}$ culture demonstrated a prolonged lag phase and did not fully enter exponential growth until day 11 . The total cell count for the $25 \mathrm{mg} / \mathrm{L} \mathrm{NiCl}_{2}$ remained lower than the control and $10 \mathrm{mg} / \mathrm{L}$ flasks by the end of the study. The $50 \mathrm{mg} / \mathrm{L}$ culture was incapable of entering the log phase, as growth of the culture was completely inhibited.

Between day 1 and day 8, a lighter pigmentation of green in the $25 \mathrm{mg} / \mathrm{L} \mathrm{NiCl}{ }_{2}$ culture was seen instead of the healthy dark green present in the control and $10 \mathrm{mg} / \mathrm{L}$
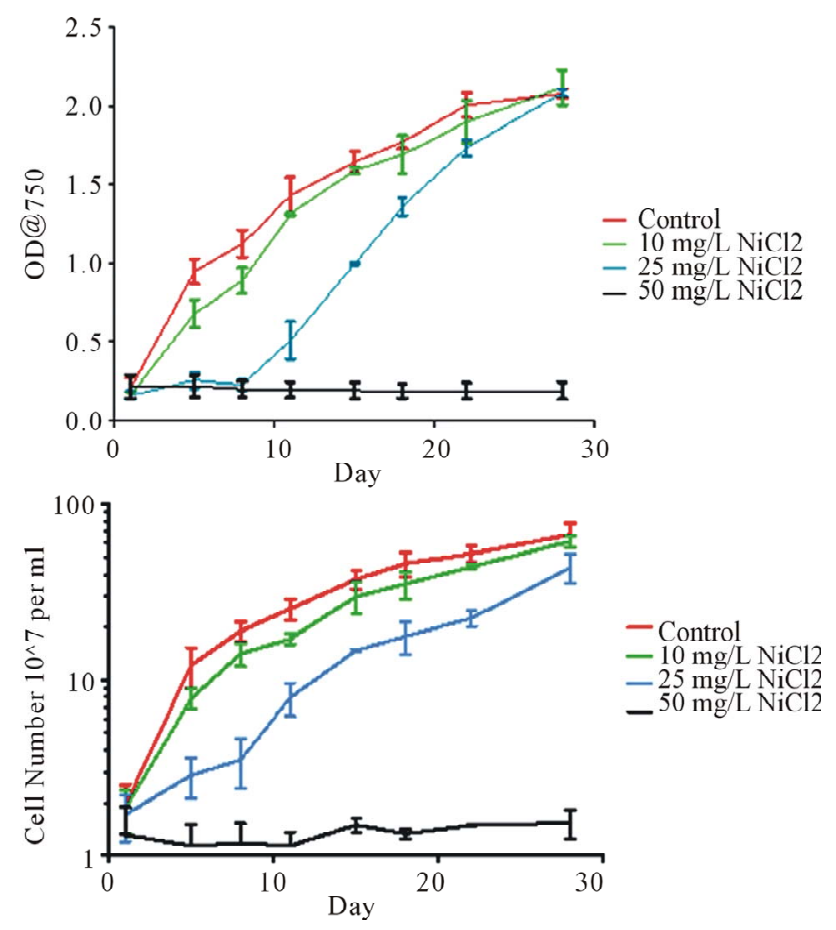

Figure 1. Growth curves of $S$. IU 625 with or without nickel chloride stress: 0 (control), 10, 25 and $50 \mathrm{mg} / \mathrm{L} \mathrm{NiCl}_{2}$, respectively. Triplicate cultures growth curves were plotted using GraphPad Prism. Top: Turbidity study with optical density at $750 \mathrm{~nm}$ of each culture plotted over the time course in days. Bottom: Direct count of cultures. 
cultures. Increases in cell number should darken the green pigmentation of the culture as demonstrated by the $10 \mathrm{mg} / \mathrm{L}$ and control cultures. S. IU 625 has a photosystem similar to that of higher plants. Nickel ions can interfere with the electron transfer in this photosystem lowering the fluorescence [21]. This suggests a bleaching effect may be seen in the $25 \mathrm{mg} / \mathrm{L}$ during its delayed lag phase.

\subsection{Initially Nickel Accumulates within S. IU 625 But Was Almost Completely Cleared by Day 11}

Nickel concentrations in the supernatant and within the cells were determined by ICP-MS. The data was normalized against the control. The $10 \mathrm{mg} / \mathrm{L} \mathrm{NiCl}_{2}$ culture accumulated $8 \%$ more nickel in the cells by day 5 and by day 11 it was reduced to control levels (0\%). The $25 \mathrm{mg} /$ L culture accumulated less nickel by day 5 (6\%) compared to the $10 \mathrm{mg} / \mathrm{L}$ culture. However, the $25 \mathrm{mg} / \mathrm{L}$ culture was not capable of fully driving all nickel into the supernatant. At day 15, 1\% nickel still remained in the $25 \mathrm{mg} / \mathrm{L}$ culture compared to that of the control (Figure 2).

\subsection{S. IU 625 Recovers from Nickel Chloride Induced Morphological Abnormalities}

Increases in nickel chloride concentration induce more pronounced morphological abnormalities. Cultures are capable of recovering from these defects and grow in the nickel environments. Present defects include curved morphology and nickel concentration-dependent cell size changes (Figure 3). The $10 \mathrm{mg} / \mathrm{L}$ culture had an increase in curved cells and ectopic poles. After a week, the presence of these defects declined rapidly and most cells returned to a normal morphology. The $25 \mathrm{mg} / \mathrm{L}$ culture developed similar morphological defects as the $10 \mathrm{mg} / \mathrm{L}$ culture. An increase in the presence of dead cells (as seen by the lack of DNA stain with DAPI) was seen compared to that of the $10 \mathrm{mg} / \mathrm{L}$ or control cultures. After day 11, the $25 \mathrm{mg} / \mathrm{L}$ culture was capable of growing (Figure 1) with some minor morphological defects remaining throughout the rest of the study. The $50 \mathrm{mg} / \mathrm{L}$ culture had an increased prevalence of dead cells and a decrease in cell size. By the end of the study, microscopy suggested that nearly all of cells in the $50 \mathrm{mg} / \mathrm{L}$ culture were dead. The decrease in size could be an adaptive response to minimize the cells' surface area exposed to nickel.

\section{CONCLUDING REMARKS}

In this study, we showed that $S$. IU 625 was able to tolerate nickel chloride stress up to $25 \mathrm{mg} / \mathrm{L}$. Increasing concentrations of nickel had more pronounced effects on
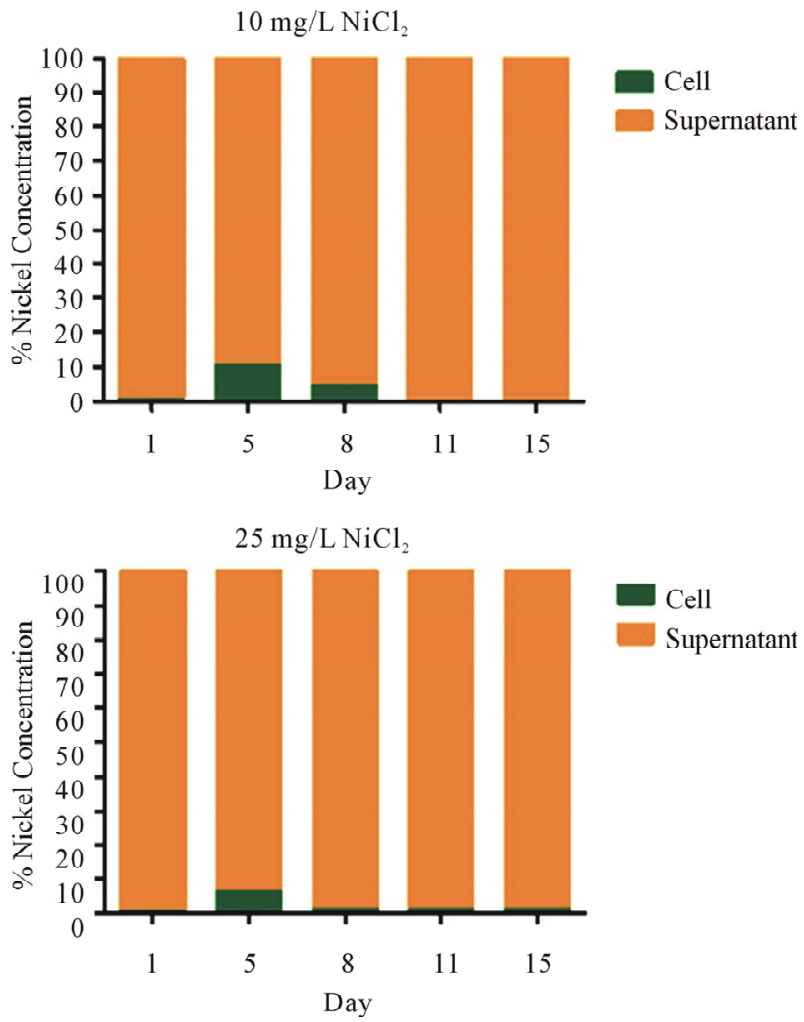

Figure 2. Distribution of nickel during the growth of $S$. IU 625. Nickel dissociates from chloride in an aqueous environment. Raw ICP-MS data was generated examining the nickel concentration against a standard. The raw data was then standardized against the control. The percentage of nickel concentration on the y axis represents the increase in intracellular nickel over the control.

both the growth rate and defect prevalence. Nickel was transported almost entirely from cells to the supernatant by surviving cultures (10 and $25 \mathrm{mg} / \mathrm{L}$ ). For cultures grown at $25 \mathrm{mg} / \mathrm{L} \mathrm{NiCl}_{2}$, nickel was undetectable inside the cells at day 11 , which also coincides with a rebound in the growth rate.

The initial qPCR data for smtA expression showed approximately a twenty-fold increase for the $25 \mathrm{mg} / \mathrm{L}$ culture up to day 11 (data not shown). Interestingly, there was no significant increase in smtA mRNA levels for the $10 \mathrm{mg} / \mathrm{L}$ culture but the nickel was still cleared from the cell based on the ICP-MS data. It suggested a possible alternative mechanism.

Future studies need to investigate other potential clearance mechanisms of nickel from the cell. Insight might be gained by identifying potential nickel resistance genes and utilizing knockout strains to examine the effects.

\section{ACKNOWLEDGEMENTS}

We deeply appreciated Naturex, Inc. (South Hackensack, New Jersey) for assisting the ICP-MS assays. This work was supported by Seton Hall University Biological Sciences Research Fund to T.C., NIH Grant 

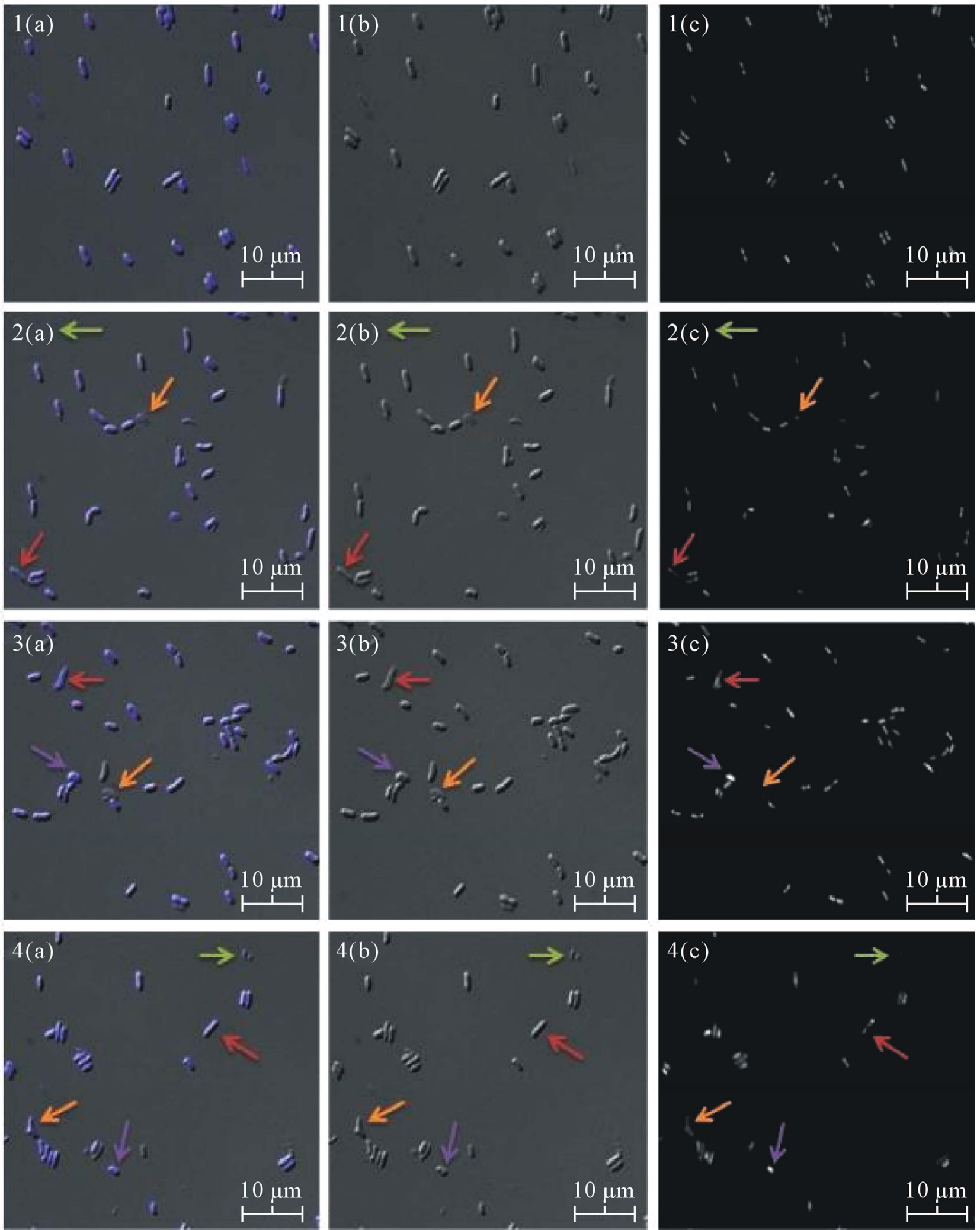

Figure 3. Microscopic observations of $S$. IU 625 with various nickel chloride concen- trations at day 13. (a) Overlaid image; (b) DIC

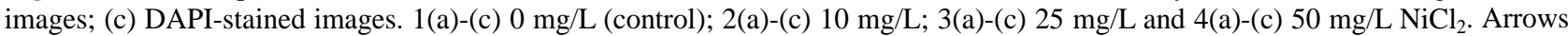
indicate different morphological abnormalities. Green arrow: normal sized cells with no DNA; Red arrow: elongated cells with DNA; Orange arrow: abnormally shaped cells with DNA; Purple arrow: cocci-like, smaller cells, with DNA. 
GM084860 to S.R.M., Montclair State University Faculty Scholarship Program to L.H.L., and CSUN IRIS support for B.T.N.

\section{REFERENCES}

[1] Brand, L.E., Pablo, J., Compton, A., Hammerschlag, N. and Mash, D.C. (2010) Cyanobacterial blooms and the occurrence of the neurotoxin beta-N-methylamino-Lalanine (BMAA) in South Florida Aquatic Food Webs. Harmful Algae, 9, 620-635. doi:10.1016/j.hal.2010.05.002

[2] Banack, S.A., Caller, T.A., and Stommel, E.W. (2010) The cyanobacteria derived toxin Beta-N-methylamino-Lalanine and amyotrophic lateral sclerosis. Toxins (Basel), 2, 2837-2850. doi:10.3390/toxins2122837

[3] Chu, T.C., Murray, S.R., Todd, J., Perez, W., Yarborough, J.R., Okafor, C. and Lee, L.H. (2012) Adaption of Synechococcus sp. IU 625 to growth in the presence of mercuric chloride. Acta Histochemica, 114, 6-11. doi:10.1016/j.acthis.2011.01.004

[4] Lee, H.L., Lustigman, B., Schwinge, V., Chiu, I.Y. and Hsu, S. (1992) Effect of mercury and cadmium on the growth of Anacystis nidulans. Bulletin of Environmental Contamination and Toxicology, 49, 272-278. doi:10.1007/BF00191766

[5] Lee, L.H. and Lustigman, B. (1996) Effect of barium and nickel on the growth of Anacystis nidulans. Bulletin of Environmental Contamination and Toxicology, 56, 985992. doi:10.1007/s001289900142

[6] Lee, L.H., Lustigman, B., Chu, I.Y. and Hsu, S. (1992) Effect of lead and cobalt on the growth of Anacystis nidulans. Bulletin of Environmental Contamination and Toxicology, 48, 230-236. doi:10.1007/BF00194376

[7] Lee, L.H., Lustigman, B., Chu, I.Y. and Jou, H.L. (1991) Effect of aluminum and $\mathrm{pH}$ on the growth of Anacystis nidulans. Bulletin of Environmental Contamination and Toxicology, 46, 720-726. doi:10.1007/BF01689958

[8] Lee, L.H., Lustigman, B. and Dandorf, D. (1994) Effect of manganese and zinc on the growth of Anacystis nidulans. Bulletin of Environmental Contamination and Toxicology, 53, 158-165. doi:10.1007/BF00205154

[9] Lee, L.H., Lustigman, B. and Maccari, J. (1993) Effect of copper on the growth of Anacystis nidulans. Bulletin of Environmental Contamination and Toxicology, 50, 600607. doi:10.1007/BF00191252

[10] Lee, L.H., Lustigman, B., Murray, S. and Koepp, S. (1999) Effect of selenium on the growth of the cyanobacterium Anacystis nidulans. Bulletin of Environmental Contamination and Toxicology, 62, 591-599. doi:10.1007/s001289900916

[11] Lee, L.H., Lustigman, B.K. and Murray, S.R. (2002) Com- bined effect of mercuric chloride and selenium dioxide on the growth of the cyanobacteria, Anacystis nidulans. Bulletin of Environmental Contamination and Toxicology, 69, 900-907. doi:10.1007/s00128-002-0144-0

[12] Lustigman, B., Lee, L.H. and Khalil, A. (1995) Effects of nickel and $\mathrm{pH}$ on the growth of Chlorella vulgaris. Bulletin of Environmental Contamination and Toxicology, 55, 73-80. doi:10.1007/BF00212391

[13] Lustigman, B., Lee, L.H., Morata, J. and Khan, F. (2000) Effect of thallium on the growth of Anacystis nidulans and Chlamydomonas reinhardtii. Bulletin of Environmental Contamination and Toxicology, 64, 565-573. doi:10.1007/s001280000040

[14] Chakraborty, P., Raghunadh Babu, P.V., Acharyya, T. and Bandyopadhyay, D. (2010) Stress and toxicity of biologically important transition metals (Co, Ni, Cu and $\mathrm{Zn}$ ) on phytoplankton in a tropical freshwater system: An investigation with pigment analysis by HPLC. Chemosphere, 80, 548-553. doi:10.1016/j.chemosphere.2010.04.039

[15] Tchou-Wong, K.M., Kiok, K., Tang, Z., Kluz, T., Arita, A., Smith, P.R., Brown, S. and Costa, M. (2011) Effects of nickel treatment on H3K4 trimethylation and gene expression. PLoS One, 6, e17728. doi:10.1371/journal.pone.0017728

[16] Zhou, X., Li, Q., Arita, A., Sun, H. and Costa, M. (2009) Effects of nickel, chromate and arsenite on histone 3 lysine methylation. Toxicology and Applied Pharmacology, 236, 78-84. doi:10.1016/j.taap.2009.01.009

[17] US Environmental Protection Agency (2010) Target analyte metals (heavy metals) and cyanide.

http://www.epa.gov/reg3hwmd/bf-lr/regional/analytical/ metals.htm

[18] Chu, T.C., Lee, L.H., Gaynor, J.J., Vega, Q.C., Lustigman, B.K. and Srinivasan, S. (2007) Identification of the Synechococcus sp. IU 625 metallothionein gene and its evolutionary relationship to the metallothionein gene of other Cyanobacteria. In: Proceeding of the 2007 International Conference on Bioinformatics \& Computational Biology. CSREA Press, 201-207.

[19] Kratz, W.A. and Myers, J. (1955) Photosynthesis and respiration of three blue-green algae. Plant Physiology, 30, 275-280. doi:10.1104/pp.30.3.275

[20] Talbot, J. and Weiss, A. (1994) Laboratory methods for ICP-MS analysis of trace metals in precipitation.

[21] Boisvert, S., Joly, D., Leclerc, S., Govindachary, S., Harnois, J. and Carpentier, R. (2007) Inhibition of the oxygen-evolving complex of photosystem II and depletion of extrinsic polypeptides by nickel. Biometals, 20, 879-889. doi:10.1007/s10534-007-9081-z 